\title{
TRABALHO DE PROFESSORES NO MEIO RURAL MARANHENSE: LEITURA A PARTIR DE "OS ESTABELECIDOS E OS OUTSIDERS"
}

\author{
Marilda da Conceição Martins ${ }^{1}$ \\ Álvaro José Camargo Vieira²
}

\begin{abstract}
Resumo
Este artigo discute o trabalho de professores de uma escola pertencente a um assentamento do Maranhão, a partir do trabalho "os estabelecidos e os outsiders" de Elias e Scotson. Este artigo, deste modo, encontra-se no âmbito de uma releitura da dissertação de mestrado, apresentada em 2010, tomando como base, conceitos como agente, sentido, estrutura e história discutidos pelos autores supracitados. A dissertação elegeu como questão principal, as implicações da ação política do Movimento dos Trabalhadores Rurais Sem Terra (MST) para a prática pedagógica dos professores de um assentamento no Maranhão. Atentamos para as seguintes questões: quem são as (os) professoras (es) que atuam nas escolas deste assentamento? As atividades e formações desenvolvidas pelo MST apresentam contribuições para a prática pedagógica destes professores? De que forma a participação e a militância no MST interfere na prática pedagógica das (os) professoras (es) do referido Assentamento? Qual a dimensão política da escola neste lugar? Utilizamos, deste modo, as contribuições da etnometodologia e dos seguintes dispositivos de pesquisa: entrevistas semi-estruturadas, questionário perfil e observação participante. Fundamentamos, portanto, este trabalho nos estudos de Beltrame (2000), Bezerra Neto (1999), Brandão (1983), Caldart (2004), Damasceno (1990), Elias (1994, 2000, 2001, 2006, 2008 e 2011), Fernandes (2000), Freire (1996).
\end{abstract}

Palavras-chave: Formação de Professores. Escolas rurais. Estabelecidos e Outsiders.

\section{TEACHERS WORK IN RURAL AREAS OF MARANHÃO STATE: READING FROM "OS ESTABELECIDOS E OS OUTSIDERS"}

\begin{abstract}
This article discusses the work of teachers of a school belonging to a settlement of Maranhão, from the work "the established and outsiders' Elias and Scotson. This article, therefore, is within a reinterpretation of the dissertation, submitted in 2010, based on concepts such as agent, direction, structure and history discussed by these authors. The dissertation elected as a main issue, the implications of policy action by the Landless Workers Movement (MST) for the pedagogical practice of teachers of a settlement in Maranhão. We look at the following questions: Who are (the) teachers (es) that operate in schools of this settlement? Activities and trainings developed by the MST feature contributions to the pedagogical practice of these teachers? How participation and militancy in MST interferes with their teaching practice of (the) teachers (s) of said Settlement? What is the political dimension of the school in this place? We use therefore the contributions of ethnomethodology and the following devices search: semi-structured interviews participant observation, questionnaire and profile. Therefore, we base this work on the studies of Beltrame (2000), Bezerra Neto (1999), Brandão (1983), Caldart (2004), Damasceno (1990), Elias (1994, 2000, 2001, 2006, 2008 and 2011), Fernandes (2000), Freire (1996).
\end{abstract}

Keywords: Teacher Training. Rural schools. Established and Outsiders.

\section{Introdução}

A sociologia das relações de poder de Nobert Elias é evidenciada, também, em sua obra, escrita em parceria com John Scotson, "Os estabelecidos e os outsiders". Este estudo refere-se a uma pesquisa etnográfica realizada em Winston Parva, nome fictício de uma pequena cidade

\footnotetext{
${ }^{1}$ Doutoranda da Faculdade de Educação da Universidade de São Paulo (FEUSP). Vinculação Institucional: Bolsista do Conselho Nacional de Desenvolvimento Científico e Tecnológico (CNPq). E-mail: liberdadema@yahoo.com.br ${ }^{2}$ Doutor pela Pontifícia Universidade Católica de São Paulo (PUC). Vinculação Institucional: Colégio São Domingos.

E-mail: alvarocamargo4@yahoo.com.br
} 
inglesa. Por meio deste estudo extenso e criterioso, no que diz respeito ao seu tempo de duração (três anos de trabalho de campo) e seu método (entrevistas, observações, análises de relatórios governamentais, dentre outros dispositivos de coleta de dados), pode-se analisar os conflitos existentes entre seus moradores, divididos em dois grupos: os estabelecidos e os "outsiders" (ELIAS; SCOTSON, 2000).

Neste trabalho sociológico, considerado um "estudo de comunidade", segundo Neiburg (2000, p. 9), “[...] o tratamento de fontes diversas permite alcançar o conjunto de pontos de vista (e de posições sociais) que formam uma figuração social, e compreender a natureza dos laços de interdependência que unem, separam e hierarquizam indivíduos e grupos sociais". Uma comunidade aparentemente "harmoniosa" e "igual" fundamenta-se exclusivamente no critério "antiguidade" para a construção do par dialético "estabelecidos" (os moradores mais antigos) e os outsiders (os recém-chegados em Winston Parva). Pela consistência empírica desta investigação, as observações nesta comunidade, contribuíram para a discussão em torno de uma teoria geral das relações de poder.

Posto isto, é no contexto destas diferentes configurações de estabelecidos-outsiders que buscamos situar a pesquisa sobre as implicações da ação política do Movimento dos Trabalhadores Sem Terra (MST) para o trabalho das (os) professoras (es) ${ }^{3}$ de um assentamento ${ }^{4}$ no Maranhão. Apesar das duas pesquisas terem sido realizadas em contextos sociais e históricos diferentes, é possível estabelecermos reflexões comparativas, são, portanto, estudos que visam articular aspectos micros e macros no processo de análise. A pesquisa sobre esse assentamento tem esta configuração centrada nos seguintes agentes: os professores militantes do MST, moradores do assentamento e os professores que não militam no Movimento e não moram no referido Assentamento.

O presente estudo buscou aproximar-se das proposições da pesquisa qualitativa, proveniente de uma abordagem etnometodológica. Esta opção metodológica, percebe o ator social como um agente que interpreta o mundo a sua volta com uma atitude que contém intenções e, portanto, projetos de ação (SCHUTZ, 1973). Buscamos, deste modo, adotar uma postura metodológica relacional e interdisciplinar, visando um equilíbrio entre os aspectos micros e macros da pesquisa, ou seja, sem focarmos demasiadamente nos agentes (sujeitos desta pesquisa) ou nos aspectos estruturais. A tentativa foi, portanto, trilhar “o caminho do meio" (ELIAS, 2008).

A coleta dos dados envolveu vários dispositivos de pesquisa, tais como: entrevistas (foram 21 sujeitos entrevistados, dentre eles, professoras (es), diretoras, coordenadores pedagógicos, coordenadores do MST), fotografias, diário de campo, observação participante (com duração de três

\footnotetext{
${ }^{3}$ Utilizamos nomenclaturas masculinas, quando possível, utilizaremos as duas nomenclaturas.

${ }^{4}$ Não identificaremos o assentamento.
} 
meses), questionário de perfil (visando levantar informações quanto ao perfil dos colaboradores deste estudo). André (2005, p.16), entretanto, adverte que "[...] não são as técnicas que definem o tipo de estudo, e sim o conhecimento que dele advém".

Apoiamo-nos na análise de conteúdo que, na concepção de Bardin (1979, p. 42), “[...] é um conjunto de técnicas das comunicações, visando obter, por procedimentos sistemáticos e objetivos de descrição do conteúdo das mensagens, indicadores (quantitativos ou não) [...] destas mensagens". Postas estas considerações, compreendemos a complexidade da natureza da análise de conteúdo, e, neste sentido, buscaremos aproximações com seus princípios e fundamentos. Para além de uma análise restrita à aparente disposição dos textos e das falas, a análise de conteúdo demanda atenção às metáforas, reticências, figuras de linguagens, entre outros indicativos que possam auxiliar na compreensão daquilo que foi dito.

Este artigo está estruturado da seguinte forma: inicialmente, discutiremos a atuação do MST no contexto da luta pela educação do campo no Brasil. Analisaremos os aspectos históricos e estruturais que contribuem para a figuração do trabalho docente no assentamento, uma vez que este ofício resulta da influência de diferentes fatores.

Posteriormente, discutiremos a etnometodologia, enquanto referencial teóricometodológico desta pesquisa e, finalmente, refletiremos sobre as implicações e os sentidos da ação política deste Movimento Social para o trabalho docente das (os) referidas (os) professoras (es), enquanto agentes deste estudo, pertencentes a grupos sociais diferentes, àqueles que moram no assentamento e militam no MST e por outro lado, os professores considerados "de fora", tanto do assentamento quanto do Movimento.

\section{Educação no meio rural maranhense}

Para analisarmos o trabalho docente no assentamento é preciso compreender este assentamento como uma figuração delineada por diferentes aspectos, tais como: a formação dos assentamentos no Maranhão, a Reforma Agrária no Brasil, as políticas nacionais de educação do campo, o perfil dos professores que trabalham nas áreas rurais maranhenses, dentre outros aspectos. Ainda que o presente artigo não dê conta de discutir todos estas questões, entretanto, consideramos importante apontá-las como variáveis que contornam as relações neste lugar.

Elias (2006, p. 26), chama a atenção para: “o perigo de partir de um indivíduo a-social [...]; e o perigo de postular um "sistema", "um todo", em suma, uma sociedade humana que existiria para além do ser humano singular, para além dos indivíduos". Visando articular aspectos micros e macros na análise de uma dada realidade social, ou seja, o equilíbrio entre a visão aérea e a do 
nadador (ELIAS, 1994) é que situamos algumas especificidades do Estado do Maranhão, como foco desta pesquisa.

Tal escolha não ocorreu de forma aleatória, pois, ao considerarmos a realidade educacional do campo, é possível perceber algumas questões alarmantes, tais como: número elevado de professores com baixa escolaridade, a desvalorização do magistério e as precárias condições de trabalho, a falta de material didático construído para a realidade campesina, estrutura física frágil das escolas, não cumprimento do calendário agrícola, entre outros aspectos. Embora não sejam problemas exclusivos do campo constituem obstáculos para que as populações rurais possam ter acesso a uma escolarização de qualidade.

De acordo com os dados do Censo Escolar de 2009, no Maranhão, grande parte dos professores que atua na educação básica, na zona rural, não está "habilitada" para esta função. Do total de docentes que trabalham na educação infantil, apenas $10,33 \%$ possui formação de nível superior completo, a maioria $(77,71 \%)$, portanto, possui o curso de Magistério, nível médio. A pesquisa revela, ainda, que $11,95 \%$ dos professores não possuem nenhuma formação específica para exercer a docência. (IBGE, 2009).

Este cenário nos traz algumas constatações: no Maranhão, a formação de professores para atuar nas escolas do campo é, ainda, um grande desafio, pois muitos dos cursos de formação inicial e continuada, quando chegam nestes espaços são destituídos de um olhar próprio e específico para a realidade local. Alguns estudos ${ }^{5}$ nos fazem perceber que as históricas condições "precárias" da educação no campo são similares em diferentes regiões do Brasil: baixos salários para os professores; escassez de materiais didáticos; escolas improvisadas ou com espaço físico limitado; ausência de merenda escolar; carência de oferta de Ensino Médio; falta de transportes escolares; ausência de programas específicos para a formação de professores; salas de aulas multisseriadas; além de outras carências repetidas e divulgadas constantemente.

Esse descaso histórico com este grupo social ainda é reforçado pela ideia propagada da mulher e do homem do campo como um ser preguiçoso, ingênuo, simples, à semelhança do estereótipo construído em torno do personagem Jeca Tatu de Monteiro Lobato.

Pobre Jeca Tatu! Como és bonito no romance e feio na realidade! "Jeca mercador, Jeca lavrador, Jeca filósofo [...]”. Quando comparece às feiras, todo mundo logo advinha o que ele traz: sempre coisas que a natureza derrama pelo mato e ao homem só custa o gesto de espichar a mão e colher [...]. Seu grande cuidado é

\footnotetext{
${ }^{5}$ Estamos nos referindo aos trabalhos de Brandão (1983), Casa de Escola; Calazans (1981), Educação Rural no Terceiro Mundo: experiências e novas alternativas; Damasceno (1990), Pedagogia do Engajamento: trabalho, prática educativa e consciência do campesinato; Demarco (2001), Uma análise do Projeto Escola do Campo; Jesus (2008), Os desafios do currículo de cursos de formação de professores para atuar nas escolas do campo; Leite (2002), Escola Rural: urbanização e políticas educacionais; Souza (2006), Educação do Campo: propostas e práticas pedagógicas do MST.
} 
espremer todas as consequências da lei do menor esforço - e nisso vai longe. (LOBATO, 2001, p. 168).

Na obra "O processo civilizador", cujo foco de Elias (2011) é trabalhar a história dos costumes e o processo histórico de civilização social por meio da internalização de regras, normas e controle de si, é possível percebermos nos manuais de Etiquetas de diferentes momentos históricos, as seguintes considerações sobre os camponeses:

[...] O comportamento nobre, cortês, é constantemente comparado com as "maneiras rudes", a conduta dos camponeses.

[...] Se deu uma mordida no pão, não o molhe novamente na travessa de uso comum. Camponeses podem fazer isso, mas não "gente fina".

[...] Se um homem bufa como foca quando come [...] e estala os beiços como um camponês bávaro, então ele renunciou a toda boa educação. (ELIAS, 2011, p. 74).

Nesta perspectiva, um dos movimentos campesinos que ganha centralidade neste processo de luta pela Educação do Campo é o MST, que tem suas origens nas articulações em torno da luta pela Reforma Agrária retomada no final da década de 70, especificamente na região Centro-Sul, e, posteriormente, expandida para as demais regiões. Atualmente, o MST tem forte representação nacional e apresenta-se como um importante defensor e divulgador dos seguintes objetivos: lutar pela terra e realizar a Reforma Agrária no Brasil. Segundo Bezerra Neto (1999, p. 10), estas lutas "não são recentes, datando do período colonial, com os povos indígenas na defesa de seu território contra as 'entradas' e 'bandeiras', patrocinadas pelo governo português e por fazendeiros da época".

A história de atuação do MST, portanto, parte da percepção de que a luta por um pedaço de chão e por educação são concomitantes e complementares, estampas de uma mesma bandeira do Movimento que reivindica direitos sociais e fundamentais para as (os) trabalhadoras (es), enquanto sujeitos capazes de construir e elaborar concepções próprias de vida. Entretanto, não foi sempre assim, pois, no início das ocupações a luta deste Movimento centrou-se intensamente na garantia de condições fundamentais e básicas, como, a posse da terra, habitação, saneamento básico e condições próprias e estruturais de cultivo da terra.

Para garantir esta educação, organizam-se, no interior do Movimento, as seguintes estratégias de reivindicação: elaboração da proposta pedagógica do MST; formação de professoras e professores; criação do Setor de Educação em 1987. Isto permitiu a ampliar o acesso dos camponeses à Educação Básica e ao Ensino Superior. Para Caldart (2004, p. 92), o MST incorporou a escola em sua dinâmica das seguintes formas:

A escola passou a fazer parte do cotidiano e das preocupações das famílias Sem Terra, com maior ou menor intensidade, com significados diversos, dependendo da própria trajetória de cada grupo, mas inegavelmente já consolidada como sua marca cultural: acampamento e assentamento do sem-terra do MST têm que ter 
escola e, de preferência, que não seja uma escola qualquer; e a escola passou a ser vista como uma questão também política, quer dizer, como parte da estratégia de luta pela Reforma Agrária, vinculada às preocupações gerais do Movimento com a formação de seus sujeitos.

A escola é percebida, portanto, como instituição importante na formação política dos sujeitos que operarão a transformação social, contribuindo, deste modo, para "uma rede nacional de luta e resistência" dos trabalhadores Sem Terra (FERNANDES, 2000). As experiências do Movimento no campo da educação e na organização de ideias, convicções e formulações constituem referências e diretrizes que consubstanciarão a elaboração de novas concepções pedagógicas atendendo às especificidades do campo.

A formação do professor no MST está relacionada ao desenvolvimento de matrizes pedagógicas permeadas por práticas e vivências que contribuem com a formação da identidade, bem como humanização dos Sem Terra, chamadas por Caldart (2004) de Pedagogia do Movimento. Com isto, a autora não quer dizer que o MST tenha inventado uma nova Pedagogia para formar o (a) professor (a), mas que ao produzir uma educação adequada às necessidades sócio-políticas dos Sem-Terra, criou-se uma maneira original de utilizar as matrizes pedagógicas herdadas ao longo da história da humanidade.

$\mathrm{Na}$ percepção de Gohn (2003), os trabalhos educacionais realizados pelo MST fundamentam-se em princípios que podem ser assim, definidos: a educação é um processo amplo e não se desenvolve apenas na escola; a luta por educação estrutura-se em torno da demanda de uma escola pública com qualidade; a escola em questão deve ter a identidade do campo, valorizando a cultura e o saber da população camponesa; e, por fim, a formação do professor e da professora revela a estrutura dorsal do processo educativo, que deve ser uma ação coletiva.

A formação do docente proposta pelo MST deve, portanto, levar em consideração os aspectos e princípios presentes na própria dinâmica do Movimento. Para Caldart (1997), quando se fala em formação docente no MST, deve-se considerar uma série de atividades que se realizam na esfera nacional, regional, estadual e municipal. A intenção é a de permitir ao professor, a discussão e a formação nos aspectos pedagógicos e políticos, a partir das seguintes atividades: encontros, seminários e cursos breves em cada uma das frentes de trabalho educacional, participação das educadoras e educadores nos coletivos e nas lutas do Setor de Educação e do MST como um todo, sistematização das práticas pedagógicas das diversas frentes, dentre outras.

As atividades propostas pelo MST para a formação docente realizam aquilo que Giroux (1997) chama de formação de professoras (es) como intelectuais críticas (os), que atuarão no sistema educacional a partir de suas concepções de resistências às injustiças e desigualdades sociais 
e análise crítica dos fatos educacionais, buscando promover a emancipação social dos sujeitos envolvidos no processo educacional (FREIRE, 1996).

Formar o (a) professor (a) do campo, portanto, contribui para a realização desta proposta de educação integral defendida pelo Movimento, que através das suas atividades e múltiplas Pedagogias, possibilita o rompimento do latifúndio do conhecimento, democratizando, deste modo, o saber enquanto bem cultural da humanidade, capaz de redimensionar a vida daqueles que dele se servem.

O nosso olhar investigativo, portanto, esteve atento aos movimentos da prática docente do assentamento Diamante Negro Jutaih, no sentido de compreender a relação entre as práticas docentes e as implicações da ação política do MST. Além disto, atentamos para a configuração das relações entre os professores militantes e os professores não-militantes do MST. Esse assentamento é uma referência maranhense, uma vez que a articulação das famílias foi fundamental para o processo de ocupação, que teve como apoio inicial as discussões da Igreja Católica, grupo de produtores rurais sem-terra e do Sindicato dos Trabalhadores Rurais (STR) do município maranhense Igarapé do Meio, local onde aconteceram as reuniões com as famílias da comunidade.

A história desta Vila é contada e recontada por vários assentados, que participaram diretamente das mobilizações e das ocupações. Após a conquista da terra, as famílias do assentamento, à semelhança do que acontece em outros assentamentos brasileiros, perceberam que era preciso conquistar outros direitos básicos, dentre eles, a educação. Autores como Caldart (2004), Bezerra Neto (1999) e Morigi (2003) referenciam a máxima do MST de que é preciso romper com as cercas da ignorância. Nesta perspectiva, a luta por escolas no assentamento, como era de se esperar, veio marcada por muitas reivindicações. Esta comunidade possui atualmente três escolas de ensino fundamental, representando uma conquista importante para as famílias assentadas. Entretanto, este aspecto revela-se insuficiente, uma vez que os estudantes deslocam-se para o município vizinho, no intuito de concluir o Ensino Médio.

A conquista da escola neste assentamento, especificamente, traz a necessidade de se refletir sobre algumas questões: Quem são os professores que atuam nestes espaços? O que pensam sobre a escola campesina? Existem diferenças entre o trabalho pedagógico dos professores "de dentro" (militantes) e dos “de fora” (não-militantes) do MST?

\section{Com a palavra, as (os) professoras (es): algumas considerações}

Oito atores sociais, apesar de termos entrevistado e conversado com praticamente todos os funcionários da escola, um dirigente nacional do Movimento, alguns moradores, estudantes e funcionários da Secretaria de Educação de Igarapé do Meio - foram colaboradores diretos deste 
estudo. Os professores em questão possuem características diferentes que permitem apreender diferentes modos de assimilar e se relacionar com a ação política do Movimento. Entre eles encontram-se professores militantes e não-militantes do Movimento; moradores e não-moradores do Assentamento; professores contratados e concursados; iniciantes na profissão e professores com mais de 15 anos de serviço.

A professora Olga ${ }^{6}$, por exemplo, é formada em Pedagogia da Terra pela Universidade Federal do Rio Grande do Norte (UFRN) em parceria com o MST. Iniciou seu trabalho de professora aos 12 anos, como "professora de reforço" e, posteriormente continuou suas atividades como docente da educação infantil. Atualmente, ensina na terceira série do Ensino Fundamental, no turno da manhã e à tarde trabalha com as disciplinas Filosofia, Artes e Ensino Religioso, nas turmas de quinta e sexta série da escola Luzia Mendes. Focamos as observações das aulas e o trabalho realizado por esta professora prioritariamente na turma da manhã, terceira série, por ser um espaço privilegiado e de atuação "exclusiva” desta professora. É importante lembrar, também, que Olga é concursada e trabalha apenas na escola do Assentamento.

A professora Felipa é, também, formada em Pedagogia da Terra, resultado de uma parceria do MST com a Universidade Federal do Pará (UFPA). Suas características profissionais assemelham-se com as de Olga. É concursada e atualmente, trabalha na escola Raimundo Cabral, pela manhã, com a Educação Infantil e à noite é professora da escola Luzia Mendes nas turmas de EJA, ministrando a disciplina de Filosofia e Artes. Além de trabalhar nas escolas do Assentamento, Felipa trabalha como supervisora escolar em Igarapé do Meio. As observações das suas aulas e trabalhos focaram a turma de EJA, momento em que tivemos contato com os estudantes, bem como interagimos com os mesmos.

Formada em Letras pela UEMA, Hannah é professora de Língua Portuguesa nas turmas de EJA e do Ensino Fundamental "regular" nas escolas do assentamento. Há dois anos trabalha nestas escolas, ministrando a referida disciplina; além de ser professora em outras escolas nas cidades maranhenses de Santa Inês e Monção, onde atua como professora de Língua Portuguesa do Ensino Médio e Ensino Fundamental. Por não morar no Assentamento e não ser militante do MST, acreditamos que sua participação é relevante para este estudo.

O professor Bem é formado no curso técnico em Magistério e, atualmente, é estudante do Curso Pró-Infantil, uma parceria da Prefeitura Municipal de Igarapé do Meio com a Universidade Estadual do Maranhão e, além disso, trabalha na escola da Vila há quase dois anos. Este professor, contratado, leciona atualmente em uma turma de Educação Infantil e não possui trabalho em outro

\footnotetext{
${ }^{6}$ Os nomes dos sujeitos participantes da pesquisa foram preservados e em seu lugar atribuímos outros nomes, com o intuito de guardar suas identidades. Além disto, as transcrições das falas dos sujeitos buscaram a maior aproximação com seus enunciados originais.
} 
estabelecimento de ensino. Perfil semelhante é apresentado pela professora Garrida que possui o Ensino Médio e, atualmente, estuda no Curso Pró-infantil. Há dois anos trabalha como professora contratada na educação infantil, experiência possibilitada pelos seus estudos no referido curso e, há menos de um ano, trabalha no assentamento.

Além de morar no Assentamento e de se considerar "parcialmente" uma militante do MST, a professora Calu é concursada e formada em Letras pela UEMA, leciona pela manhã na turma da segunda série do Ensino Fundamental na Escola Luzia Mendes e à tarde trabalha nas turmas de quinta e sexta série a disciplina Língua Portuguesa. Calu é, também, diretora de uma escola estadual da cidade de Igarapé do Meio. Sua atuação como professora na escola da Vila soma um período de dezesseis anos. Neste sentido, é importante afirmarmos que nossas observações focaram a segunda série, por considerarmos um espaço de maior contato com o trabalho desta professora.

A professora Maria é formada em História pela UEMA e, atualmente, leciona a disciplina História e Ensino Religioso nas turmas de EJA e do Ensino Fundamental, da escola Luzia Mendes. Maria não mora no Assentamento e não é militante do Movimento, além disto, está iniciando a carreira de professora, e é recém-concursada pela Prefeitura de Igarapé do Meio. A situação de morar longe e de trabalhar a noite faz com que esta professora, assim como tantos outros que trabalham neste lugar, enfrente os perigos de uma estrada mal sinalizada e esburacada, para ir e voltar cotidianamente do trabalho para casa.

A professora Ester é formada em Letras pela UEMA, é professora da segunda série do ensino fundamental. Há 15 anos trabalha no Assentamento e não possui outro emprego além deste. O fato de ser concursada propicia a esta professora, assim como para as demais uma segurança e maior tranquilidade em relação a sua permanência na escola. A sua condição de professora é permeada pela vontade de concretização de um "sonho", conforme percebemos em sua fala. Para muitas professoras do campo e até mesmo da cidade, a docência vem manifestada pela percepção de "vocação" e "dom", contribuindo para diminuir o caráter profissional do trabalho docente (NÓVOA, 1995). Estes "relatos orais de vida" se entrecruzam nos seguintes aspectos: a proveniência campesina destes docentes, o fato de serem professores das escolas rurais, terem estudado em escolas campesinas, o caminho tortuoso em busca da formação docente, dentre outros aspectos.

Durante a realização da pesquisa pudemos perceber diferentes configurações do tipo estabelecidos e outsiders no assentamento. Em relação aos professores, por exemplo, há uma barreira perceptível entre aqueles que são militantes e os que não são militantes do MST; os moradores e os não-moradores do Assentamento; os que participam e aqueles que não participam das atividades desenvolvidas pela comunidade assentada; entre os concursados e os contratados, 
dentre outras "segregações". Entretanto, o elemento que adquiriu visivelmente um peso maior foi "o local de moradia" dos professores, uma vez que os professores "de fora" do assentamento eram tidos como "não-participantes" das atividades realizadas pela escola, além de não respeitarem a "realidade" dos estudantes.

Elias e Scotson (2000, p. 20) atentam para a figuração estabelecidos-outsiders, "paradigma-empírico" construído a partir do estudo da comunidade de Winston Parva, pois as famílias antigas desta cidade, "consideravam-se humanamente superiores aos residentes da parte vizinha da comunidade, de formação mais recente. Recusavam-se a manter qualquer contato social com eles, exceto o exigido por suas atividades profissionais". Do mesmo modo que os grupos considerados mais poderosos, na maioria desses casos, "veem-se como pessoas 'melhores', dotadas de uma espécie de carisma grupal, de uma virtude específica que é compartilhada por todos os seus membros e que falta aos outros" (p. 20).

Assim como em Winston Parva, o assentamento contava com um sistema complexo de "fofocas", de diferentes enfoques, e "em todas as suas diversas formas, as fofocas tinha um valor considerável como entretenimento" (ELIAS; SCOTSON, 2000, p. 122). No fluxo da fofoca depreciativa circundava a avaliação do trabalho dos professores, sobretudo "dos de fora", percebidos como àqueles que fazem o "contra-trabalho". As falas abaixo, obtidas por meio de entrevistas, ilustram o conflito entre os professores moradores e os não-moradores do assentamento.

QUADRO 1: Impressões das professoras moradoras do assentamento sobre os professores "de fora" porque ele disse pros meninos que se encontrasse os meninos vendendo maxixe, não era pra dizer que era aluno dele. Agente ficou muito aborrecido com isso. Vender maxixe não é vergonha, não. Vender maxixe significa que ele produziu maxixe. Então, agente trabalha muito isso, o conhecimento a partir do ser, do conhecimento, e com a sua história. Eu não posso morar no assentamento, ser quebradeira de coco e me apresentar como médica. O Movimento trabalha muito isso também, a gente tem que trabalhar o ser, a partir do que ele é. 
Professora Calu

Professora Felipa

Professora Ester

Professora Olga
Aqui nós já fomos conhecido como a escola “conserta" professor. Porque nós não aceitávamos que alguém viesse pra escola trabalhar só o dia que ele queria. [...] Nós já conseguimos experiências muito boa [com os professores de "fora], conseguimos aproveitar a experiência pro que é diferente.

Aqui só os professores que moram no assentamento podem ser diretores da escola. Temos medo de perder nossa autonomia.

Infelizmente o que coloca professora pra dentro de uma sala de aula, hoje é um concurso público, porque o pessoal da Vila não passa e vem professor de fora que só dá sua aula e pronto.

Fonte: Dados da pesquisa realizada em 2010.

QUADRO 2: Impressões das professoras não-moradoras do assentamento sobre os professores "de dentro"

Professoras não-moradoras do assentamento Sobre os professores "de dentro"

Tenho muito cuidado com o que falo, eles daqui são muito politizados. Então, muda, muda muita coisa. E, como eu tô nas duas escolas ao mesmo tempo. Lá eu trabalho de um jeito. Aqui eu já tenho alguns cuidados de tá diferenciando algumas coisas, na questão da sala de aula, dos conteúdos, 
da própria linguagem, né. É tipo assim, uma Maria aqui e lá é outra Maria. Ouvi dizer que aqui eles devolvem os professores que não fazem um bom trabalho.

Professora Maria

Assim, todo mundo falava lá em Igarapé do Meio, que esse pessoal daqui é muito polêmico, esse negócio de assentamento diz que brigam muito e não sei o quê. Aí a maioria das minhas colegas dizia assim, Garrida se eu fosse tu eu não ia, esse negócio é muito chato eles expulsam professor. Aí pensei, não é possível que eles vão me expulsar de lá, aí eu fiquei com medo, mas vim encarar pra ver o quê que dá.

Professora Garrida

Professora Hannah

Muda muito. Eu enfrentei “enes" desafios, eu enfrento. Não, até que hoje mudou. Mas, no início o fato de [...] dizem que eu sou polêmica. Eu não vejo que eu seja polêmica. Geralmente, eu argumento as coisas. [...] E, o fato deu não morar no assentamento, complica muito, mas eu vejo que, como eu disse, que o assentamento, é "quase um condomínio fechado", porque não é nem três quilômetros, dá pra você ir tranquilamente. Mas, o fato deu não ter participado do Movimento, talvez tenha implicado mais. É, isso também implica, porque só o preconceito, que tinham ou que tem, em relação a mim, ao meu trabalho. 
Professor Bem
Eu to fazendo a minha parte de professor,

mesmo não sendo do Movimento.

Fonte: Dados da pesquisa realizada em 2010.

O que diferencia, sobretudo, estes dois grupos de professoras é a trajetória de formação desenvolvida por cada uma delas. As professoras do MST participam de cursos, formações, seminários, marchas realizadas pelo Movimento, aspecto que fortalece suas discussões sobre a educação do campo. Elas apresentam, deste modo, um discurso bem fundamentado e articulado acerca da realidade campesina e dos princípios de educação idealizados pelo MST.

Esta "consciência orgulhosa", conforme afirma Beltrame (2000), é muito presente nas falas das professoras, que se mostram fascinadas e orgulhosas por suas condições de Sem- Terra e, de consequentemente, poderem trabalhar suas histórias e falar com prazer sobre o processo de ocupação da terra no assentamento. Além disto, os professores falam sobre como valorizam a realidade sócio-cultural dos educandos, bem como os princípios do MST como componentes do currículo escolar.

Ao longo da pesquisa, observamos, a partir dos diferentes depoimentos das professoras, a articulação entre a militância dos professores e suas práticas docentes. Para as professoras participantes do MST, o trabalho na escola deve refletir o engajamento de suas militâncias no Movimento, isto, portanto, gera por parte das docentes uma cobrança pessoal em relação as suas práticas pedagógicas. O peso do "olhar" julgador de seus companheiros de "militância" é algo presente, por isso, o grande esforço dos professores militantes para não serem “criticados" pelos colegas de trabalho, uma vez que "a opinião interna do grupo com alto grau de coesão tem uma profunda influência em seus membros, como forma reguladora de seus sentimentos e sua conduta" (ELIAS; SCOTSON, 2000, p. 39).

O conflito entre estes dois grupos possui diferentes causas históricas, dentre elas, a percepção da zona rural como lugar de castigo, fato que leva muitos professores da zona urbana, na maioria das vezes, a serem mandados para lá como forma de "punição", por terem desagradados a política partidária local. Em relação aos professores não-militantes do MST, percebemos que seus trabalhos são marcados, na maioria das vezes, pelo medo de "serem expulsos" da Vila, pois, alguns destes professores são "amedrontados", antes mesmo de chegarem ao Assentamento, conforme demonstrado acima, na fala da professora Felipa. 
A preocupação com a aprendizagem dos estudantes, a qualidade do ensino e a reflexão crítica do trabalho docente, não são tarefas apenas de quem participa de um Movimento Social, compreendemos que estas ações devem ser realizadas pelos professores de uma forma geral. Há uma facilidade por parte das professoras moradoras do Assentamento de lidarem com as discussões referentes ao MST em sala de aula, por se sentirem mais à vontade para lidar com estas questões, diferentemente de alguns professores que não moram no Assentamento.

O próprio termo como são chamados "os professores de fora", já expressa uma condição de "não pertencimento" ao grupo, uma vez que estão "de fora" daquilo que a escola trabalha ou até mesmo, pensa em concretizar. Durante a permanência da pesquisadora do assentamento, não pretendemos fazer uma análise "julgadora" daquilo que seria um bom e um mau professor. Entretanto, percebemos que alguns professores moradores do assentamento eram, de fato, mais envolvidos nas atividades da escola do que os professores que não moravam no assentamento. Isto é justificado pelos professores não-moradores: excesso de trabalho, diferentes escolas e pertencentes a outras comunidades.

Ao analisar historicamente o trabalho dos professores do assentamento, é possível perceber, segundo as entrevistas, que este assentamento costuma receber professores "de fora" que desenvolvem experiências educativas interessantes e diferenciadas. Além disso, percebemos que ser professor do assentamento e militante do MST não é condição sine qua non para o desenvolvimento de uma prática pedagógica crítica.

[...] os grupos ligados entre si sob a forma de uma configuração de estabelecidosoutsiders são compostos de seres humanos individuais. O problema é saber como e por que os indivíduos percebem uns aos outros como pertencentes a um mesmo grupo e se incluem mutuamente dentro das fronteiras grupais que estabelecem ao dizer "nós" enquanto, ao mesmo tempo, excluem outros serem humanos a quem se referem coletivamente como eles. (ELIAS; SCOTSON, 2000, p.37).

Diante disto, a fala de Calu resgata a ideia de trabalhar "o ser a partir do que ele é". Isto é um desafio para o professor, uma vez que ele muitas vezes não dispõe de condições concretas para a realização de um trabalho docente atencioso e sensível às reais necessidades do público para quem trabalha. É preciso, pois, romper com a visão discriminatória que vislumbra na profissão do camponês o atraso e a vergonha social. Concordamos com Nóvoa (1995) ao dizer que uma formação docente crítica ajuda estes profissionais a compreender melhor a sua prática e desejando melhorá-la.

Além do conflito entre estes grupos de professores, constatamos, também, a complexidade presente no processo de construção de um projeto crítico e emancipador de educação do campo no Brasil. A luta em defesa da educação do campo, que respeite os camponeses, suas vidas, seus 
sonhos, seus projetos de vida, ainda é presente e fortemente requerida por esta população e pelos Movimentos Sociais do Campo, a exemplo do MST. (MORIGI, 2003).

A escola pertencente ao Assentamento é considerada uma das instituições mais importantes desse lugar, sendo capaz de mobilizar ações de luta dentro e fora das terras assentadas. Esta instituição carrega o símbolo das contradições do MST e da comunidade assentada, pois ao mesmo tempo em que questiona, ela reproduz as práticas de exclusão socialmente vigentes. Novamente as professoras apontam como crise no trabalho escolar do assentamento, a falta de unidade e articulação entre os professores, sobretudo a falta de "socialização" dos professores "de fora", recém-chegados ao assentamento. Para a professora Felipa:

Eu ainda acho que a escola é o único jeito, que a gente tem de retomar as coisas. Mas, a escola tá crescendo, muita gente de fora tá chegando. Nós somos um grupo inicial, muito reduzido, em relação a todos os outros professores. E a gente acaba ficando reduzido em tudo. À noite, de todos os professores, poucos vivenciaram todo esse processo, que passou por altos e baixos nessa escola, que já passou por grande tristeza, que depois da crítica, da autocrítica, que a gente fazia a cada ano, no meio do ano, a gente fazia.

Há, portanto, a convicção de que a escola pode ser um instrumento de luta dentro do Assentamento, a partir da formação política dos estudantes e da comunidade, tendo em vista todas as suas contribuições no processo de organização do Assentamento, bem como na luta pela legalização da posse da terra. A crise de identidade que a escola vivencia hoje é perpassada pela necessidade de reestruturação dos ideais de luta dos assentados e pelo resgate da coletividade e da unidade dentro do Assentamento. Elias e Scotson (2000, p. 22) afirmam:

Um exemplo das constantes estruturais nas relações entre estabelecidos e outsiders poderá ajudar os leitores a descobrirem outras por si mesmos. Como indica o estudo de Winston Parva, o grupo estabelecido tende a atribuir ao conjunto do grupo outsider as características "ruins" de sua porção "pior" - de sua minoria anômica. Em contraste, a autoimagem do grupo estabelecido tende a se modelar em seu setor exemplar - na minoria de seus "melhores" membros. Essa distorção pars pro toto, em direções opostas, faculta do grupo estabelecido suas afirmações a si mesmo e aos outros; há sempre algum fato para provar que o próprio grupo é "bom" e que o outro é "ruim".

Outra luta empreendida, diz respeito à necessidade de autonomia por parte da escola, fato que é visto pela Secretaria Municipal de Educação de Igarapé do Meio como algo que exime sua responsabilidade pedagógica e financeira com este estabelecimento de ensino. Segundo a professora Ester:

Nossa relação com a Secretaria de Educação, aparentemente ela parece ser harmoniosa, mas nem tanto. A gente sofre muita discriminação. Quando as coisas chegam aqui, é quando nenhum outro lugar quis. Eles discriminam muito a gente, muito mesmo. Mas, eu entendo que eles discriminam é porque eles têm é medo. $\mathrm{O}$ assentamento com seu poder de organização, já teve em Igarapé do 
Meio, já fez manifestação. E isso gerou um receio até, por parte do poder público. E isso gerou a discriminação, porque quando a gente reivindica, a gente cobra.

A luta contra a intervenção da política partidária dentro da escola do Assentamento é nítida, uma vez que a presença de funcionários “contratados", neste espaço, é vista como ameaça à autonomia da escola. Por outro lado, a falta de emprego no campo, o jogo político partidário, a "retomada" do voto de cabresto forma um grupo de pessoas que fica suscetível à vontade política e que necessita de emprego, enfim, de uma renda para sobreviver. Mesmo que para isto, se aceite o emprego temporário, garantido pela "venda" do voto, fato que revela uma situação, ainda bastante presente no campo brasileiro (DAMASCENO, 1990).

As contribuições do MST são apontadas pelas (os) professoras (es) como necessárias para a escola, para o trabalho e para a formação docente, uma vez que por meio da reivindicação e da militância das populações camponesas e do MST, estabeleceu parcerias com universidades, secretarias de educação, garantindo a algumas professoras assentadas a realização de um curso superior. Observamos, entretanto, a necessidade deste Movimento retomar a discussão em torno da formação de professores, bem como da formação política da comunidade assentada, tendo em vista a retomada da luta coletiva pelas melhorias do Assentamento, tanto num âmbito educacional como num aspecto mais geral.

A (o) professora (or), neste contexto, é vista (o) pela comunidade como uma liderança capaz de formar pessoas críticas, além de ser guardiã dos bons costumes do povo. As (os) professoras (es) moradoras (es) do Assentamento são, deste modo, solicitadas (os) para direcionar quase todas as atividades realizadas dentro do assentamento, desde a festa da igreja até a campanha de vacinação. Diante disto, é possível perceber o orgulho e o prazer demonstrados por estas (es) profissionais em serem camponesas (es) e professoras (es) deste lugar, aspectos proporcionados, também, pelo status que possuem dentro do Assentamento. Para a professora Calu:

Então, o professor aqui, ele tem um papel assim, de membro de todas as atividades. Tudo é o professor. Se é numa celebração, as coisas, os professores estão envolvidos. Se é na festa do Assentamento, os professores estão envolvidos. Se é na quadrilha os professores estão envolvidos, se é na vacina, tu tá lá, ajudando a conversar com as crianças, que não dói e tal. Então, em todos os lugares que o professor chega aqui no assentamento, ele tá contribuindo com este assentamento, nas discussões, nas ações, em tudo. Professor aqui... é tudo.

Ao resgatarmos a história de vida das (os) professoras (es), pudemos perceber os seus esforços empreendidos na luta pelo acesso à educação básica, bem como à educação superior. A escolha e a busca pelo magistério foram permeadas por dificuldades, distâncias e saudades, aspectos que foram superados com o apoio de suas famílias, sobretudo. Notamos que as (os) professoras (es) do assentamento, que não são militantes do MST, mesmo tendo experiências com a educação do 
campo, carecem de uma formação pedagógica específica pautada nos princípios da educação campesina.

Sobre as implicações do MST para a prática pedagógica das (os) professoras (es) do assentamento, constatamos a partir das entrevistas e das conversas realizadas que há por parte daquelas (es) que são militantes do MST, uma preocupação mais acentuada em trabalhar os princípios, as músicas, as palavras de ordens, os eventos comemorativos com base nas propostas defendidas pelo MST. Nem todas as (os) professoras (es) não-militantes do MST conhecem o projeto de educação proposto pelo Movimento, nem mesmo o Projeto Político Pedagógico da escola do Assentamento. Em conformidade com Caldart (2004), este fato contribui para distanciar as (os) professoras (es) da realização de um trabalho voltado para os ideais de educação "emancipadora", além de reforçar as relações de estabelecidos-outsiders. (ELIAS; SCOTSON, 2000).

O mal-estar entre professoras (es) militantes e não-militantes do MST é bastante perceptível, uma vez que para as (os) primeiras (os), a maioria das (os) professoras (es) que não moram no Assentamento, não se envolvem nas atividades da escola; não comparecem aos planejamentos mensais e não conhecem a realidade do Assentamento. Para as (os) professoras (es) que não militam no MST, as (os) professoras (es) militantes do Movimento, as tratam com discriminação ao decidirem sobre as ações da escola, não permitirem que os professores de "fora" sejam diretores, e por ameaçar "devolver" as (os) professoras (es) que não fizerem um bom trabalho no Assentamento. Segundo a professora Hannah:

É bem polêmico. Não vamos nós aqui, ser hipócrita, nada é aleatório. Se você tem um Movimento, você tem uma ideologia. Tem uma ideia de dinamismo e tem uma ideia de dominação. Tu pode achar estranho, mas que é verdade é, por exemplo, vou dá um exemplo aqui que vai fugir um pouquinho, se tu estuda numa escola de padre, na escola de padre tu tem uma ideologia. [...] Aqui o Movimento também não foge isso. A escola do Movimento ela vai seguir a linha do Movimento. Ela quer passar uma ideologia, uma ideologia política. E uma forma de se lembrar essas lutas.

A luta pela implantação de uma pedagogia "crítica" no assentamento, segundo os colaboradores da pesquisa, já foi mais intensa. Notamos, portanto, o saudosismo, as dúvidas em torno do que fazer, como retomar as antigas ações reivindicativas da escola, as mobilizações, a coletividade dentro da escola e do Assentamento. Concordamos com Elias (2001, p. 24), ao afirmar que "este quadro preto e branco pintado com o sentimento do bom passado, mau presente não serve a qualquer propósito". Esta pedagogia da dúvida, portanto, tem gerado imobilismo entre o que já foi feito e o que se pode fazer, dentro das condições apresentadas pela escola, pelos sujeitos envolvidos no processo educativo.

Nos planejamentos didáticos, notamos uma "solidão" pedagógica, pois, mesmo quando as (os) professoras (es) conseguem se reunir para planejar, há um silenciamento, proporcionado pelo 
medo da exposição, do pedir ajuda. Entre as (os) professoras (es) que moram no Assentamento existe uma sintonia maior no trabalho, no planejamento das atividades, na organização das festividades da escola, mesmo que elas sejam organizadas a qualquer momento e em qualquer dia.

Constatamos, ainda, que a pedagogia da festa é presente e muito solicitada pelas (os) professoras (es) do assentamento e pela comunidade assentada. A atenção dada a estes momentos festivos (GAETA, 2008), que fazem parte do calendário dos trabalhadores, adotado pelo MST, é visto pelas (os) professoras (es) como um diferencial de seus trabalhos em relação às (os) professoras (es) das outras escolas. Notamos, entretanto, a necessidade de uma articulação e integração entre essas atividades festivas e o trabalho em sala de aula, desenvolvidas pelas (os) professoras (es).

Entre a Secretaria Municipal de Educação e a escola do assentamento existe um distanciamento muito forte, o que envolve desentendimentos e falta de comunicação entre professoras (es) e funcionárias (os) da Secretaria de Educação. Os assentados sinalizam a má qualidade da merenda escolar, falta de professores, infraestrutura da escola comprometida, com poucos espaços, sem iluminação, além da falta de formação contínua para os professores. Ao conversarmos com representantes da Secretaria de Educação, entretanto, estes aspectos parecem não existir e para cada um destes apontamentos há sempre um plano e um projeto idealizado.

Sobre a prática pedagógica das professoras do assentamento podemos afirmar que existem experiências focalizadas e que se diferenciam, ou seja, algumas (ns) professoras (es) militantes destacam-se por possuir maior envolvimento com o trabalho da escola e com os ideais do MST, possuem, portanto, uma prática e uma fala articulada com este ideais. Por outro lado existem professoras (es) não-militantes envolvidas (os) interessadas (os) em conhecer a discussão sobre a educação do campo, e que demonstram preocupação e envolvimento com a realização do trabalho docente. A partir das "cenas" da sala de aula acompanhamos os trabalhos dessas (es) professoras (es), os desafios, o empenho, a dedicação e a complexidade que permeia a prática pedagógica da (o) professora (or).

A escola e as (os) professoras (es) do assentamento, portanto, carregam o peso de trabalharem numa instituição de ensino supervalorizada como espaço de instrução, formação de cidadania e transformação social (TAMARIT, 2000). Estas constatações são também construídas pela comunidade assentada, que questiona e participa deste processo dialético. Deste modo, elas são construídas a partir das observações e da tentativa de escuta atenciosa das vozes ecoadas dos atores sociais do assentamento, nos levam a muitos questionamentos, uma vez que estamos no movimento da travessia. 
A pedagogia dos aços, emprestada da poesia de Pedro Tierra, serve de inspiração para esta pesquisa, no sentido de ratificar a força dos assentados em suas disputas pela terra, por dignidade humana e por educação. Esse processo histórico, doloroso, esperançoso de luta pela escola não pode ser esquecido, uma vez que dentre as conquistas do Assentamento a escola é tida como uma das mais importantes. É preciso, deste modo, que as (os) professoras (es) do assentamento estejam unidas (os) para realizar uma prática pedagógica que tenha como princípio a educação do campo construída com a escola e com a comunidade.

A atuação do MST no processo de formação docente, deste modo, é vista pelos assentados como essencial para que a escola e a comunidade lutem por dias melhores e pela tão clamada justiça social. É necessário que sejam construídas propostas de formações contínuas com todos as (os) professora professoras (es) e funcionárias (os) da escola do assentamento, pois percebemos a necessidade de envolvimento de todos (as) os seus membros e não apenas as (os) professoras (es) militantes ou os não-militantes nas atividades da escola.militantes ou os não-militantes nas atividades da escola. Para além desse segregacionismo é preciso que se rompa com o maniqueísmo entre o trabalho dos funcionários militantes e o dos não-militantes do MST.

Muitos aspectos foram mencionados ao realizarmos esta pesquisa e muitos outros precisariam de maior atenção, entretanto, atentamos para os limites de uma pesquisa deste porte, diante da complexidade e amplitude da realidade social, sempre contraditória, cheia de impurezas e sempre num movimento dialético. Percebemos, deste modo, a partir da realização desta pesquisa e da nossa aproximação com o MST, a necessidade de uma luta contínua, mesmo que tudo pareça sem sentido, sem perspectiva. É preciso acreditar e ter esperança na possibilidade de mudança, agarrando-nos aos sonhos, aos desejos e à procura.

A história de luta e de vida dos assentados é inspiradora porque nos remete a uma história dolorosa e ao mesmo tempo vitoriosa de camponesas (es) que acreditaram que era possível vencer juntos, em fila, reunidos, marchando, derrubando as cercas, sorrindo, chorando, mas seguindo firme em direção ao alvo. Acreditamos que esta mesma comunidade ainda vive e ainda segue em frente, sem desistir desta luta.

A integração, portanto, entre estes dois grupos de professores, aqui chamados de estabelecidos-outsiders (ELIAS; SCOTSON, 2000), torna-se um elemento importante para a reconfiguração do trabalho docente nesta comunidade. Deste modo, ser um professor "de fora" não significa ser um mau professor; da mesma forma que ser professor não significa ser um bom professor. Para Elias e Scotson (2000, p. 181), "nenhum desses grupos poderia ter-se transformado no que era independentemente do outro. Eles só puderam encaixar-se nos papéis de estabelecidos e outsiders por serem interdependentes". Essa interdependência entre os professores do assentamento 
precisa ser percebida como um elemento formativo, uma vez que a aprendizagem da docência se dá, também, de forma coletiva, que deve ir além do "segregacionismo pedagógico".

\section{Referências}

ANDRÉ, M. E. D. A de. Estudo de caso em pesquisa e avaliação educacional. Brasília: Líber, 2005.

BARDIN, L. Análise do conteúdo. Lisboa: Ed. 70, 1979.

BELTRAME, S. A. B. MST, professores e professoras: sujeitos em movimento. 2000. Tese (Doutorado em Educação) - Faculdade de Educação, Universidade de São Paulo. São Paulo, 2000.

BEZERRA NETO, L. Sem-Terra aprende e ensina: um estudo sobre as práticas educativas e formativas do Movimento dos Trabalhadores Rurais Sem Terra. Campinas, SP: Autores Associados, 1999.

BRANDÃO, C. R. Casa de Escola. Campinas, SP: Papirus, 1983.

CALDART, R. S. Educação em movimento: formação de educadores e educadoras no MST. Petrópolis, RJ: Vozes, 1997.

. Pedagogia do Movimento Sem Terra. São Paulo: Expressão Popular, 2004.

CALAZANS, M. J. Educação Rural no Terceiro Mundo: experiências e novas Alternativas. Rio de Janeiro: Paz e Terra, 1981.

DAMASCENO, M. N. Pedagogia do Engajamento: trabalho, prática educativa e consciência do campesinato. Fortaleza: UFC, 1990.

DEMARCO, D. J. Uma análise do Projeto Escola do Campo: Casa Familiar Rural como iniciativa de profissionalização e escolarização de jovens rurais do Estado do Paraná. 2001. $188 \mathrm{f}$. Dissertação (Mestrado em Educação) - Faculdade de Educação, Universidade de São Paulo. São Paulo, 2001.

ELIAS, N. Escritos e ensaios. Rio de Jnaeiro: Zahar, 2006.

. Introdução à Sociologia. Lisboa-Portugal: Edições 70, 2008.

. O processo civilizador: uma história dos costumes. Rio de Janeiro: Zahar, 2011.

. A sociedade dos indivíduos. Rio de Janeiro: Zahar, 1994.

A solidão dos moribundos. Rio de Janiero: Zahar, 2001.

; SCOTSON, J, L. Os estabelecidos e os outsiders. Rio de Janeiro: Zahar, 2000.

FERNANDES, B. M. A formação do MST no Brasil. Petrópolis, RJ: Vozes, 2000.

FREIRE, P. Pedagogia da Autonomia: saberes necessários à prática educativa. São Paulo: Paz e Terra, 1996. 
GAETA, M. A. J. V. As festas escolares como lugares de sensibilidades e subjetividades. In: Congresso LUSO-BRASILEIRO DE HISTÓRIA DA EDUCAÇÃO: Cultura Escolar, Migrações e Cidadania, 7., 2008, Porto. Actas... Porto: Universidade do Porto, 2008. p. 1-9.

GIROUX, H. A. Os professores como intelectuais. Porto Alegre: Artes Médicas, 1997.

GOHN, M. da G. Movimentos Sociais no início do século XXI: antigos e novos atores sociais. Petrópolis, RJ: Vozes, 2003.

INSTITUTO BRASILEIRO DE GEOGRAFIA E ESTATÍSTICAS (IBGE). Dados do censo escolar de 2009. Disponível em:

http://www.in.gov.br/visualiza/index.jsp?data=23/09/2009\&jornal=1\&pagina=11\&totalArquivos=7 04. Acesso em: 10 jan. 2011.

JESUS, S. M. S. A. Os desafios do currículo de cursos de formação de professores para atuar nas escolas do campo. In: ENCONTRO NACIONAL DE DIDÁTICA E PRÁTICA, 14., 2008, Porto Alegre. Anais... Porto Alegre: EdiPUCRS, 2008. p. 648-665.

LEITE, S. C. Escola Rural: urbanização e políticas educacionais. São Paulo: Cortez, 2002.

LOBATO, J. B. M. Urupês. São Paulo: Brasiliense, 2001.

MACEDO, R. S. A etnopesquisa crítica e multirreferencial nas ciências humanas e na educação. Salvador: EDUFBA, 2000.

MORIGI, V. Escola do MST: uma utopia em construção. Porto Alegre: Mediação, 2003.

NEIBURG, F. A sociologia das relações de poder de Nobert Elias. In: ELIAS, N; SCOTSON, J. L. Os estabelecidos e os outsiders: sociologia das relações de poder a partir de uma pequena comunidade. Rio de Janeiro: Jorge Zahar, 2000.

NÓVOA, A. Os professores e a sua profissão. Lisboa: Dom Quixote, 1995.

SCHUTZ, A. Collected Papers I: the problem of Social Reality. The Hague: Nijhoff, 1973.

SOUZA, M. A. Educação do campo: propostas e práticas pedagógicas do MST. Petrópolis, RJ: Vozes, 2006.

TAMARIT, J. Educar o Soberano: crítica ao iluminismo pedagógico de ontem e de hoje. São Paulo: Cortez, 2000. 